\title{
Reification and Fetishism: Processes of Transformation
}

\author{
Sónia Silva
}

Skidmore College, USA

\begin{abstract}
Reification, fetishism, alienation, mastery, and control - these are some of the key concepts of modernity that have been battered and beaten by postmoderns and nonmoderns alike, with Bruno Latour, a nonmodern, discarding them most recently. Critical of this approach, which creates a rift between moderns and nonmoderns, the author engages in dialogue with modern thinkers - particularly Peter Berger, Thomas Luckmann and Stanley Pullberg - with a view to recycling and redefining the concept of reification from a nonmodern perspective. Marxian scholars associate reification with an attitude of detachment and passivity. Drawing on two years of ethnographic fieldwork in a Luvale-speaking region of northwest Zambia, Africa, the author seeks to convert the negative and asymmetrical Marxian reading of reification, which places subjects above objects, to a positive symmetry. Marx explained the capitalist economy through the lens of religion. Reversing the direction of symmetrical comparison, the author considers the northwestern Zambian universe of ancestors and their different mahamba manifestations in the form of spiritual beings, diseased bodies and material objects through the lens of Marxian concepts, mainly reification and fetishism. Three aspects of reification understood as a human universal come to light: first, reification and animation entail each other both in the realms of materiality (human bodies and material objects) and immateriality (concepts and spirits), being best perceived as a form of fetishism. Reifacts are fetishes and fetishes are reifacts. Second, because fetishes are animated and do things, reification is a form of engagement with the world, a means to action and a tool for transformation. Third and last, and without contradiction, reification entails engagement and detachment, action and withdrawal, control and surrender. There is much to gain from recycling the old concept of reification. In a non-partisan symmetrical perspective, the redefinition of reification as fetishism yields a new, positive understanding of the place of material and immaterial things in social life and the ways in which we humans apprehend the
\end{abstract}

Corresponding author:

Sónia Silva, Skidmore College, Assistant Professor of Anthropology, 218 Tisch Learning Center, Saratoga Springs, NY 12866, USA.

Email: ssilva@skidmore.edu

http://www.sagepub.net/tcs/ 
world and implicate those things in our projects and struggles. Reification is not an impediment to action but a condition for action.

\section{Keywords}

animation, fetish, materiality and immateriality, reification, subject and object, symmetrical anthropology, transformation

Monsieur le Capital and Madame la Terre do their haunting simultaneously as social characters and as mere objects. (Karl Marx)

Ask someone to offer an example of a fetish, and he or she will probably mention a non-genital object of sexual gratification, maybe velvet, a handkerchief, or a foot; an object of religious veneration in some distant land, maybe a crude carving or a stone; or an emblematic commodity in capitalist societies, maybe the cell phone or money itself. If your interlocutor is an art aficionado, he or she may also mention the avant-garde object, thus completing the four classic arenas of the Euro-American fascination with fetishism: sex, religion, economy and art. All these fetishes are material objects. The word 'fetish' itself derives from the Latin facticius, 'a thing made'. As often, though, 'things' take the form not of material objects but of abstractions apprehended as autonomous entities. Fetishes do not share their ontological status, physical appearance, or functional attributes; they share their being reifacts. To speak of fetishism is to speak of reification, the universal human tendency to apprehend abstractions as things.

Far from new, this insight appears in Karl Marx's early writings as well as in Capital, where Marx, speaking of commodity fetishism in capitalist societies, defines it as a peculiar phenomenon in which 'a definite relation between men [assumes] the fantastic form of a relation between things' (Marx, 1936 [1867]: 83). Two themes in Marx's writings on commodity fetishism have inspired my own work: one is Marx's recognition of the interconnectedness between fetishism and reification (Fetischismus and Verdinglichung in the original German). The other theme is what I call, after Bruno Latour, symmetrical anthropology, or the tactful employment of one and the same explanation or standard to the terms of our comparisons, however we define these relative terms and positions (Latour, 1993). Marx sought to grasp the phenomenology of commodities in the capitalist market through the lens of "the mist-enveloped regions of the religious world' (Marx, 1936 [1867]: 83), a world he encountered in the written work of such literati as the French magistrate and philosopher Charles de Brosses (1760), author of the term fétichisme. ${ }^{1}$ Marx writes: '[the capitalist commodity] is a very queer thing, abounding in metaphysical subtleties 
and theological niceties' (Marx, 1936 [1867]: 81). I rejoin Marx in upholding the value of symmetrical comparison.

This said, my anthropology differs from Marx's in important ways. Marx brought the religious worlds of far-off territories to illuminate capitalism. Reversing the direction of symmetrical comparison, I bring the insights developed by Marx and Marxian scholars in the context of capitalism to bear on the ancestral world of a Luvale-speaking region in northwest Zambia, where I have conducted over two years of fieldwork on the topic of fetishism and divination (Silva, 2011).

I also differ from Marx in terms of the qualitative value that we ascribe to fetishism and reification. Both Marx and numerous scholars whom he has inspired see fetishism and reification in negative terms. In their view, human subjects should never reduce themselves to objects, in the process of forgetting their authorship of the world and granting autonomy to their creations. Human subjects and material objects should never fuse or become symmetrical. Marx is symmetrical when he explains economy and religion using the same concepts, as noted. He is asymmetrical in his treatment of subjects and objects. I will attempt to turn this asymmetry into a positive symmetry by showing that reification is intertwined with animation wherever it appears, being best perceived not as a form of false consciousness that results in paralysis but as a form of engagement and transformative action.

To this end, I will engage in conversation with a group of select sociologists whose work on reification is discernibly Marxian in spite of their disclaimers. I will not engage in direct dialogue with Marx, who used the concept of reification only once (Pitkin, 1987: 264), ${ }^{2}$ or even with the Hungarian Marxist philosopher and literary critic György Lukács, the first scholar to fully develop the theoretical and political implications of reification, ultimately restricting this concept to the historical context of late capitalism (Lukács, 1971 [1923]). I will instead converse with three sociologists whose view of reification, being Lukácsian, is once again symmetrical: I mean Peter Berger, Thomas Luckmann and Stanley Pullberg. Two seminal publications will be at the center of this debate: 'Reification and the sociological critique of consciousness', an essay published in 1965 by Berger and Pullberg, and The Social Construction of Reality, a book published one year later by Berger and Luckmann. ${ }^{3}$

Why, you may ask, revisit the old Marxian concept of reification? Have not poststructuralist and neocolonialist theorists put that concept to rest once and for all, denouncing it as a western narrative steeped in imperialism and the sort of dualisms typical of modernity (Bewes, 2002)? Has not Latour, more recently, depicted Marxists as the moderns par excellence, the strongest of believers in belief (Latour, 1993: 126)?

To build what he calls the Middle Kingdom, where the broken halves of dualism are brought together and made whole, Latour critiques the moderns and discards many of their concepts. Out the window he throws 
belief, magic, fact and fetish, fetishism and anti-fetishism, subject and object, production, alienation, reification, surpassing, mastery, and also critical thought (Latour, 2010: 18, 35). These concepts, Latour notes, are caught up in the Great Divide between a delusory us and a delusory them, a free, masterful subject and an alienating object. But does the important work of critiquing and suspending the belief in belief require that we abandon valuable old concepts? Do we really need to throw the baby out with the bath water?

Notwithstanding the brilliance and originality of Latour's $(1999,2010)$ factish theory - his Middle Kingdom - my ethnographic fieldwork in northwest Zambia has convinced me that there is much to gain from recycling (not salvaging) the old concept of reification and its long-time associates mastery and control from the wasteland of modernity. I hope that by critically engaging with Berger, Luckmann and Pullberg - all the while drawing inspiration from both Marx and more recent scholars of fetishism, including Latour ${ }^{4}-\mathrm{I}_{\text {can }}$ demonstrate that it is not possible to understand fetishes as separate from reifacts. Fetishes are reifacts and reifacts are fetishes. Nor is it possible to understand reifacts-fetishes as separate from the hybrid control-surrender. Why create another Great Divide between moderns and nonmoderns, depriving ourselves of the contributions of the former? Here too I rather concentrate on bridgework and let critical theorists and agnostic theorists, those who believe in belief and those who suspend that belief, meet in the middle. ${ }^{5}$

With this project in mind, let us take for a start not Latour's concept of factish or hybrid or quasi-object quasi-subject, but the old, battered definition of reification that Berger and Luckmann present in their treatise The Social Construction of Reality:

Reification is the apprehension of human phenomena as if they were things, that is, in non-human or possibly supra-human terms. Another way of saying this is that reification is the apprehension of the products of human activity as if they were something else than human products - such as facts of nature, results of cosmic laws, or manifestations of divine will. Reification implies that man is capable of forgetting his own authorship of the human world... The reified world is, by definition, a dehumanized world. It is experienced by man as a strange facticity, an opus alienum over which he has no control rather than as the opus proprium of his own productive activity. (Berger and Luckmann, 1966: 82-3, italics in the original)

I will use three key dimensions of reification presented in this excerpt to frame my critical appraisal and to structure this article: the apprehension of human phenomena as things; the forgetting of human authorship and 
the consequent alienation of the producers from their products, a condition described by Berger and Luckmann as dehumanizing; and the producers' lack of control over their own products. The authors claim that reification is a universal phenomenon that recurs in space and time. I argue that, for that very reason, we should not define it, as they do, in the terms in which it becomes expressed in the historical context of late capitalism in Europe and North America - as a dehumanizing condition. Reification is always and necessarily linked not with inertness but with responsiveness; not with detachment but with involvement; not with passivity but with activity; not with a lack of control over one's products, but with a tighter control over those products and the advantages they bring. In the end, a different view of mastery and control will surface: to regain control and effect change it is not sufficient to adopt a critical stance and come to terms with the 'objective' fact that our reified world is after all our own creation, and what we did ourselves we can undo. To regain control and effect change we must accept that, in that very process, we will relinquish control, forget our authorship, and infuse our products with both reality and anima. There is no control without surrender; there is no transformation without reification.

Much like fetishism, reification has been negatively depicted time and again. On one side, Marxian scholars have denounced reification as a misapprehension and a form of distorted praxis. On the other side, Whiteheadian scholars have defined reification (hypostatization) as the 'fallacy of misplaced concreteness', the name given by the mathematician and philosopher Alfred Whitehead (1925: 74-5) to the tendency among intellectuals to see their analytic concepts as autonomous things. In spite of all this negativity, I have found the old and loaded idea of reification most illuminating and thought-provoking, and have emerged from my voyage through modernity with a new, positive understanding of the place of things in social life and the ways in which we humans apprehend the world and implicate those things in our projects and struggles.

I have also learned that there is much to gain from overcoming the pervasive tendency in academia to separate the study of reification (concepts and social relations as things) from the study of animation (tangible and intangible things as persons). ${ }^{6}$ With Marx, I hold that the reifact is a Fetischcharakter. Reification and animation are not mutually exclusive; they entail each other. This is the crux of fetishism, that performative universal whose import as a tool for transformation I seek to disclose. Let us then see how I rescue the concept of reification from negativity by redefining it afresh as fetishism.

\section{Reification, a Universal}

I mentioned earlier that Berger, Luckmann and Pullberg argue that reification is a universal phenomenon that recurs in space and time. 
Approaching reification from a phenomenological and cognitive perspective (the way phenomena appear to human consciousness and become cognized), Berger and Pullberg (1965) describe reification as the final stage in a four-stage process. They call the first stage objectivation because, as they put it, we humans embody our intentionality in the products we create, from material objects to such abstractions as names. The second stage, objectification, happens at the point in the process of objectivation in which we distance ourselves from our products and take cognizance of them as objects of consciousness. Now, not only do we objectivate, but we also recognize our products as such. Later, in the stage of alienation, as the distance between us and our products continues to grow, we forget that we ourselves created those products, which now appear to us in consciousness as 'alien facticities'. The fourth and last stage, reification, takes place when we begin to apprehend those things as not only alien but also real.

Take marriage, one of Berger, Luckmann and Pullberg's favorite examples of reification. The concept of marriage refers to the relation between spouses, their mutual responsibilities, rights and expectations, and the countless things they do for and against each other as well as others, day in, day out. Yet spouses believe that marriage is a thing out there that predetermines life and relationships, because such is the law, such is the divine will, such is the way of marriage, or such is, as some social scientists would put it, the (nearly) universal foundation of kinship systems. By forgetting that they themselves produce their marriage in the process of living in a matrimonial relationship, the three sociologists note, spouses merge with their social role and adopt an attitude of passivity and detachment toward that role as well as themselves, an attitude that is inimical to their true nature as human subjects. Thus we have a linear progression toward increasing levels of concretization as well as distancing between the producers and their products: objectivation $>$ objectification $>$ alienation $>$ reification.

The greater the distance between our products and us, the more autonomous those products become. Berger, Luckmann and Pullberg posit the idea that the level of reification in social life decreases with evolutionary time, an uncorroborated assumption that conveniently explains why it is possible for them, social scientists, to deconstruct the belief of others in AD 1965-6, straightening the record (Berger and Luckmann, 1966: 83; Berger and Pullberg, 1965: 208). Their main point, however, is paramount: 'As soon as an objective social world is established, the possibility of reification is never far away' (Berger and Luckmann, 1966: 83). In all times and places, human subjects are prone to reify. They do this by first abstracting from the concrete and then concretizing the abstract (Berger and Pullberg, 1965: 208). ${ }^{7}$ 


\section{Reification and Animation}

Having described Berger, Luckmann and Pullberg's model of reification, which they apply symmetrically to both scientists and what they call the 'men in the street', I now ask you to notice an element of negativity and asymmetry within their theoretical model. The three sociologists explain: while in the first two stages of objectivation and objectification the vital link between human subjects and their products remains intact, in the last two stages of alienation and reification that link is severed, giving rise to a negative condition defined, in Marxian terms, as profoundly dehumanizing. While the first two stages are anthropologically necessary, the last two stages may be de facto modalities of consciousness but can be overcome (and the reader is left thinking that they should be overcome, at least theoretically) if only we realize that we are the sole authors of our reified world (Berger and Pullberg, 1965: 208-10). This shift from a neutral cognitive universal to an ideologically laden valuation explains the negative portrayal of reification as dehumanizing.

Berger and Luckmann write: 'Reification can be described as an extreme step in the process of objectivation, whereby the objectivated world loses its comprehensibility as a human enterprise and becomes fixated as a non-human, non-humanizable, inert facticity' (Berger and Luckmann, 1966: 83). I concede that the world of reification is a world of things, a world where concepts and relations are turned into things. These new-made things, however, are far from inert. Did not 'fetishoaths' (oaths sworn on fetishes) seal deals between European and African merchants on the 'Guinea Coast' of West Africa in the 16th and 17th centuries? Does not commodity circulation continue to this day to naturalize the project of capitalism and help people define their identity and subjectivity as consumers? Do not social institutions continue to influence, if not determine, behavior? A reified world is not a world where inert objects abound; a reified world is a world where animated objects abound. It is not the objects themselves and the relation between objects, but the relation between objects and subjects, or reification and animation, that invites further consideration.

At this juncture, it is apposite to briefly consider the work of Roy Ellen, particularly his seminal article 'Fetishism' (Ellen, 1988), published 22 years after The Social Construction of Reality. In this article, Ellen achieves a double tour de force: he links reification and fetishism conceptually, a rare occurrence, and he turns to positive the negative value of anthropological asymmetry. Previously, the concept of fetishism had denoted forms of misapprehension - malthought in cultural evolutionism, disavowal in psychology and, as we have seen, false consciousness in Marxism. Ellen effectively turns 'fetishism' to a positive cognitive universal.

Note that in order to achieve his double tour de force, Ellen bans all traces of Marxian ideology from his approach even though he shares 
with those theorists his identity as a modern. It is worth comparing Ellen with Berger, Luckmann and Pullberg: much like the three sociologists, Ellen develops a model that is linear and fourfold. Yet he does not shift values from positive to negative but ensures that his model remains continuous from beginning to end.

In a nutshell, Ellen argues: humans are cognitively programmed to start with percepts, or the most elementary of categories dependent on sense perception, be they natural or social kinds, parts of things, or attributes. These categories they quickly reify as things or reifacts, then go on to materialize as icons, and finally to concretize as fetishes. While the icon represents an abstraction, the fetish is the abstraction. As Ellen puts it, the fetish is born when humans conflate the signifier and the signified, when the material object becomes animated. Thus we have the sequence: percepts $>$ reifacts $>$ icons $>$ fetishes. Ellen sees fetishism as a universal and, much like Berger, Luckmann and Pullberg did for reification, he perceives fetishism in terms of the linear progression concrete $>$ abstract $>$ concrete. Unlike Berger, Luckmann and Pullberg, however, Ellen does not diagnose a worrisome distancing between the producers and their products. More neutral, he traces a straight line toward the material thing in itself, thus not only achieving a truly positive anthropological symmetry but also linking reification and animation in the same conceptual model. The fetish is now the exact point where the material object becomes animated. The fetishized world is now a world of subjects (animated objects) and not a world of inert objects, as claimed by the sociologists.

Ellen's model, however, ultimately misrepresents the relation between reification and animation as well as the ethnography. Consider the ancestral world of the Luvale-speaking peoples of northwest Zambia, among whom I work. Were I to apply Ellen's linear, fourfold model to that world, I would start with the mufu, the dead person. When a person (mutu) dies, becoming a dead person (mufu), his or her life force (mwono) changes into an ancestor (mukulu). (The remaining inert body, which the relatives of the deceased will bury, is not the mufu but the chivimbi, or corpse.) An ancestor is abstracted from the concrete, perceptual reality of a dead person. It is then concretized again (reified) in the form of an autonomous entity and ontological category known as mukulu. Ancestors bear the names and social identity of dead persons, reside about the village or underground (opinions differ), and watch over their descendants with great interest. They care that the living live in harmony and behave according to shared rules of social and moral comportment. Should the living quarrel or disrespect one another, or forget their ancestors in their heart and fail to invoke them in words and inherit their names, their ancestors will punish them in the form of disease, reproductive disorders or bad luck when hunting. 
Noticeably, as punitive agents, the ancestors come out in the form of certain prototypical manifestations known as mahamba. ${ }^{8}$ Unlike the ancestors, who are idealized versions of individual dead persons, mahamba are known by a limited number of standard names as well as the physical symptoms they bring upon those they catch. Kula, for example, is a lihamba (singular of mahamba) who causes menstrual and reproductive disorders in women. Kayongo, the lihamba associated with basket divination, causes pains in the chest, breathing difficulties and possibly lunacy. In addition to manifesting themselves as diseased bodies, mahamba come out in the form of material objects during ritual ceremonies. In the world of basket divination, Kayongo's most remarkable material expression is no doubt the lipele, a personified basket containing 30 or so symbolic articles, from wooden figurines and colonial coins to animal claws. Divination baskets take part in séances as well as other rituals associated with Kayongo (Silva, 2011).

Thus we have mufu $>$ mukulu $>$ lihamba $>$ lipele. The ancestral world of northwest Zambia leads us to modify Ellen's model of fetishism by recognizing two moments in the process of conceptual reification (first mukulu, then lihamba) and omitting the stage of iconification. But these adjustments do not invalidate Ellen's model or obfuscate what he sees as the linear movement toward the most characteristic and developed form of fetishism - the lipele in the universe of basket divination. Like the shields of the Nuaulu of Seram, so beautifully described by Ellen (1990), the divination baskets of the Luvale-speaking peoples of northwest Zambia are no mere icons, images, signs or indexes of their animating spirit, Kayongo. They are Kayongo.

At first, the ethnography just presented makes good sense. One could even argue symmetrically that such linear processes of reification recur in space and time. Think of the fate of the dead in Western Europe and North America. Today (much like the ancestors in Zambia), the dead continue to be abstracted from the multifaceted reality of particular individuals, transformed into idealized persons and then materialized in the form of the belongings of the dead, their favorites objects, or maybe their photographs. Roman Catholics continue to canonize as saints those who lived 'lives of great charity and heroic virtues' and, in some cases, to subsequently honor them with material bodies in the form of statues.

On a closer look, however, if one cares to listen to what people say and observe what they do, one will realize that the relation between reification and animation is not linear. Neither is it locked in the material world, as Ellen argues. Reification is entailed with animation in whatever realm it appears, material or immaterial, visible or invisible. All reifacts are animated to some degree. Some reifacts are even personified. Analytically, it may seem that we reify in order to animate, a process that suggests a temporal and causal relation in which animation negates or surmounts reification. Experientially, however, reification and animation are best 
described as a simultaneity, a co-presence, a coincidence, even - momentarily - a unity. There is no linear movement from reifact to fetish. There is only the mutual entailment and affirmation of reification and animation in different realms of existence, material and immaterial, and the expression of that entailment in the modes that are possible in those realms. Thus we have: fetish $>$ fetish $>$ fetish; which is to say, fetish.

In my descriptive account of the universe of ancestors and their manifestations in northwest Zambia, presented above, I led you to see a linear movement from the concrete reality of the dead person to the concrete reality of the personified material object (the fetish) via the abstraction of the mukulu ancestor and his or her mahamba manifestations (the reifacts). This linear movement is an artifact of Ellen's model (and, likely, of the interviewing process during fieldwork as well). Now I ask that you notice the mutual entailment of reification and animation at work not only in the material realm of the divination basket but also in the immaterial realm of the ancestors and their manifestations. Ancestor the reifact is also ancestor the fetish: An ancestor is simultaneously an alien facticity and a personified entity named after a dead person and endowed with a keen sense of observation, judgment and morality, as well as a harsh personality. Mahamba the reifacts are also mahamba the fetishes: Again, as autonomous ontological entities, the origins of mahamba as human products are lost to consciousness. Yet mahamba are fully animated and even personified, having names of their own, idiosyncratic personality traits and the power to act. Kayongo is cruel and pitiless. He likes blood and other things red, from iron oxide to the scarlet wing feathers of the touraco; and he will kill you, slowly. Then, as mentioned, there is the lipele. This material oracle is a reifact because it results from the materialization of an abstraction - lihamba Kayongo. Yet, being a reifact, it is also fully animated and personified. During séances, the lipele listens to the diviner's questions and responds in the form of meaningful configurations of small material articles. The lipele also goes through a life course that includes a nightlong ceremony of initiation into adulthood and a special burial to signal its death (Silva, 2011).

In sum, there is no movement toward the thing in itself. There is only an array of manifestations of the same phenomenon in different realms of existence - realms that people distinguish, no doubt, much as they distinguish persons and things (vatu and vyuma), without permanently fixing the distinctions. Fetishes are fetishes regardless of their different expressions.

The analytical traditions of fetishism predispose us to locate fetishes in the material, tangible world. But we should not let the scandalous presence of the fetish-object blind us from seeing other fetishes in the nonmaterial world. In all realms of existence, the universal human tendency to reify and the universal human tendency to animate converge and intertwine to the point where there is not one without the other, to the 
point where they coincide and may, momentarily, become one. Ours is a world of converging differences and relative discontinuities. It is a world where the correlated distinctions between subjects and objects, materiality and immateriality, ritual and religion, cognition and acts, and consciousness and practice may be stressed or effaced, confirmed or surpassed.

I opened this article with the following statement: to speak of fetishism is to speak of the larger whole of reification. Having reconsidered these concepts in conversation with moderns from a nonmodern perspective, I am now led to the opposite conclusion: to speak of reification is to speak of the larger whole of fetishism. We humans reify and animate all the time. We are master fetishists.

\section{Control and Surrender}

It is now time to return to Berger, Luckmann and Pullberg to broach another point of disagreement between us. I quote Berger and Luckmann once more: 'The reified world is, by definition, a dehumanized world. It is experienced by man as a strange facticity, an opus alienum over which he has no control rather than as the opus proprium of his own productive activity' (Berger and Luckmann, 1966: 82-3). One year earlier Berger and Pullberg had written: 'In producing an alienated world, the human is devalued and a humanity is produced that is characterized by inert objectivity' (Berger and Pullberg, 1965: 204). All three sociologists stress that reification is dehumanizing because when we forget that we are the sole authors of our products, we forget ourselves as subjects and become objects both to ourselves and to others. The social world becomes a world of objects, a strange world over which we have no control.

Many of you who live in Europe and North America will be familiar with this discourse of reification (or objectification in today's parlance). After the long eclipse that followed the 1960s, the discourse of reification, according to the philosopher Axel Honneth (2008: 17-21), is back again. Scholars as well as artists have returned to this old idea, and there has been much talk about the vexed problem of the objectification, commoditization and trafficking of human beings and their body parts. These are serious matters that unleash suffering and consternation. This said, it is important to realize that reification is not coextensive with its expression as a passive, dehumanizing condition in European and North American recent history. In positive symmetrical perspective, reification (redefined as fetishism) is best described in non-judgmental and non-partisan terms as an act of invested engagement in the world in the hope of ensuring some measure of control. Wherever you go, whichever country you visit, you will find people living their lives in particular circumstances, trying to be heard, struggling to accomplish small and large goals, hoping to make 
a difference. It is in those particular circumstances that people, including scientists, actively fetishize. This accomplishment is possible because where there is reification, there is animation, as shown, and where there is animation there is engagement, investment and empowerment in the hope of transformation.

I should clarify at this juncture that transformation is not always positive on political and moral grounds. I noted the objectification, commoditization and even trafficking of human beings, processes in which people are shamelessly belittled, degraded, silenced and exploited. And we all know of reified concepts that have led to personal and collective suffering, if not horror. Think of the portrayal of Tutsis as 'cockroaches' by the Hutus prior to the Rwandan genocide. Think of the thousands of so-called 'fallen women' in 20th-century Ireland who were sent to the Magdalene asylums, true camps of forced labor and systematic dehumanization. Think of the innumerable students in the high schools of the United States and other countries who are called 'nerds', 'weirdos' and whatnot, in addition to suffering other forms of bullying. Such negative reifacts as 'cockroaches', 'fallen women' and 'weirdos' share with positive reifacts the important fact that they engender change and transformation. We may say that degrading reifacts are mere distortions that say and reveal nothing. We may say that they are mere illusions or selfaggrandizing delusions. For the sake of the Tutsis, the Irish women, the American high school students and all of us, we should recognize, as they do, that such distortions are very serious and very real, that negative reification does things, from injuring the victims and empowering the perpetrators to reproducing the conditions under which such acts become possible.

And this observation leads us to the important point that reification, cognitively predicated though it may be, is always enacted contextually. Only by considering the critical contexts - historical, sociocultural, political, economic, interactional and existential - in which subjects who are also objects engage with objects who are also subjects in pursuit of transformation, positive or negative, can we possibly comprehend the universal impetus to fetishize.

Consider again the ancestral world of northwest Zambia. Ancestors and their mahamba manifestations enable transformation and an accrued sense of control in highly particular social contexts and existential circumstances. Outside these contexts and these circumstances (which is to say, in scholarly writing), the ancestral world becomes reified as an ontological flux endlessly turning from ancestral spirit to human body to material object and back again, continually flowing and coagulating with neither direction nor purpose.

There are at least three critical contexts without which this ancestral world remains eerily adrift: the first context is the suffering human body. Mahamba make themselves known in the form of physical symptoms: 
fever, headaches, respiratory disorders, chest pain, miscarriages, barrenness, sores and boils, lunacy. Mahamba are felt and endured before they are cognized. The second context is ritual. As the symptoms worsen and the afflicted person begins to waste away, his or her relatives will likely consult a basket diviner to identify the agent behind so much suffering. Should that agent be an ancestor, the diviner will also pin down the specific lihamba mode in which the ancestor has emerged and prescribe the conduction of a healing ritual known by the name of that lihamba. During the healing ritual, people will sing and clap, play the drums, invoke their ancestor, and manipulate myriad substances and objects, hoping to appease and persuade the lihamba to come out in the form of material objects and, in some cases, possession trance. Now, in local understanding, none of the above can be understood outside the larger context of social relations. This is the third context. The consulted diviner will have informed his clients that ancestor so-and-so came out as lihamba so-and-so because his or her descendants harbored ill feelings toward one another or forgot to honor their ancestor. In addition to possible herbal treatments, healing requires both the performance of the prescribed ritual and the resolution (in theory at least) of the festering interpersonal animosities that led to the problem in the first place. Body, ritual and social relations: these are three of the critical contexts without which fetishism, in the particular context of illness and misfortune caused by ancestors in northwest Zambia, would vanish into thin air.

I thus far have argued that reification, being the converse of animation, does not lead to the dehumanization of the world but to the humanization of the world; that we fetishize when we want to accomplish a goal, to persuade, demean, heal, find comfort, control, transform; and that it is not possible to understand the significance of fetishism in social life without considering the multiplicity of contexts in which it is bound to appear. My next point follows: if, as I have argued, reification and animation entail and affirm each other, reification is not an impediment to action but a condition for action.

In fairness, I should say that Berger, Luckmann and Pullberg explicitly recognize the link between reification and social action. 'We ourselves produce the world from which we are alienated', Berger and Pullberg (1965: 203) write. 'Even while apprehending the world in reified terms, man continues to produce it', Berger and Luckmann (1966: 83) note. The problem, from my perspective, is that the three sociologists see reification as an entirely negative condition, defining it, for example, in the words of Berger and Pullberg, as 'objectification in an alienated mode' (Berger and Pullberg, 1965: 200) or as the very moment in which 'the dialectical process in its totality ["men" producing society and society producing "men"] is lost' (Berger and Pullberg, 1965: 207). Hence their viewing of the link between reification and social action as a paradox, a social world that is produced by objects. 
Underlying this negative, asymmetrical view of social reification is the deep-rooted Hegelian idea that subjects are not only opposed to objects as distinct ontological categories, but also stand over and above objects. In Marxian terms, subjects should never forget their authorship of the world, forget themselves in their forgetfulness, adopt an attitude of passivity and detachment (a 'contemplative stance' in the words of Lukács [1971 (1923): 98]), spend their lives in a mystified, ultimately diminishing mode. Subjects should never become objects. But what if this view of social life is distorted? What if objects are also subjects, and subjects, objects? What if in order to become a subject one must become an object? What if in order to act one must withdraw?

My engagement with the ideas of select moderns has persuaded me that reification does involve the forgetting of our authorship of the social world and our withdrawal into passivity, processes that Lukács identified. We may even describe reification as alienating in the sense that the products we create appear to us as alien facticities, as Berger, Luckmann and Pullberg described. At the same time, however, we must recognize that reification is a process of active involvement in the world in search of transformation. Both sides are constitutive of reification redefined as fetishism. Action and withdrawal are mutually entailed. There is nothing paradoxical here.

Neither is there anything paradoxical in the fact that people both control and are controlled by the fetishes they create ('this paradoxical tension is very characteristic of fetishes', Ellen writes [1988: 229]). It is true that all fetishes reduce our choices and freedom to act as autonomous subjects, which we never are. It is equally true that we act through them, that we produce the world through them, that we change the world through them.

In his devastating critique of modernity, Latour (2010: 11) urges us to detoxify ourselves of the drug of mastery (his metaphor), which the moderns see as the locus of subjectivity and control over facts and nature in opposition to that other drug of theirs, alienation. But does the important work of deconstructing the belief in belief require that we discard these old concepts and the insights that they offer? Why should we not engage with them, recycle them, turn them inside out, if that will take us to where we want and need to go? Once recycled and neutralized as forms of control and surrender, mastery and alienation are mutually entailed instead of mutually exclusive. Rather than standing along in a kingly posture, mastery entails and presupposes the humbling alienation of the subject. Nowhere is there sweet without sour, up without down, light without darkness, taking without giving, action without coercion, revolution without oppression, learning without suffering. Nowhere is there control without surrender.

I came to this realization in northwest Zambia, where the necessity of withdrawal in the process of engagement is given elaborate cultural expression in so-called rituals of affliction (Janzen, 1992; Turner, 1968). 
Those of you who are familiar with the early work of anthropologist Victor Turner among the Ndembu of northwest Zambia (an ethnic group that is socially and historically related to the Luvale-speaking peoples) will recall that rituals of affliction are long, complex performances for healing the ills caused by an ancestor (Turner, 1968). You will also recall that the afflicted, once healed, become healers. Illness is the pathway to ritual expertise. Suffering is the pathway to knowledge and social recognition.

The same ethos reappears in several ritual domains. During ritual, the same lihamba that punished you in the form of disease will take hold of you in the form of possession trance in order to cure you. (Here, the process of reification is complete because the sick person, once possessed in the form of trance, completely loses both control and self-awareness.) All this so you can be healed and become a ritual expert. Equally notorious are the prescriptions and proscriptions that accompany ritual work and life as a healer. Marxist anthropologist Maurice Godelier states, 'Taboos, prohibitions, constraints do not mean any restriction of power, rather an accumulation of it' (Godelier, 1977: 179). They mean both. There is no power without obligation.

In sum, in animating their spirits, people in northwest Zambia willingly surrender to regain some degree of control - much in the same way that people do in capitalist societies in animating their commodities. The differences between these points of comparison are many, of course, one in particular coming to mind: in northwest Zambia, the loss of control is experienced and verbally described as suffering, whereas in Europe and North America that loss is often described as apathy, detachment, numbness, sleepwalking - in short, a disturbing if oddly painless condition. Maybe the rituals of affliction in northwest Zambia will inspire social theorists of late capitalism to reckon with the suffering that lies restless just beneath the skin, and to conceptualize that suffering as an existential powerhouse and a political weapon.

\section{Transformation}

Karl Marx symmetrically explained capitalism in the light of 'the mistenveloped regions of the religious world'. I hope that my brief, equally symmetrical accounts of fetishism in Africa in the light of Marxian writings will be of relevance to those readers, critical or agnostic, who share an interest in fetishism and reification in different times and places, including Europe and North America.

I also hope to have succeeded in converting the asymmetry that underlies Marxian writings on reification to a vigorous positive symmetry. To this end, I developed a critique of the old Marxian view of reification as an attitude of detachment and passivity, a view first theorized by Lukács for the historical conditions of late capitalism and later modified 
by Berger, Luckmann and Pullberg to a de facto, if depoliticized, universal. In addition, I redefined reification as the reverse of animation. I gained this insight from the ancestral world of northwest Zambia as much as from Marx, who, in Capital, not coincidentally, preferred the concept of fetishism (Fetischismus) to reification (Verdinglichung). In the middle, where the critical and the agnostic meet and dialogue, reification is no longer a sign of paralysis, an obstacle to revolutionary consciousness, a bad omen. Reification is a form of action and a tool for transformation, positive or negative, revolutionary or reactionary, substantial or minuscule.

There is much to gain from recycling the old concept of reification from the wasteland of modernity and dissociating it from other germane concepts such as mystification and false consciousness. Only in this way will we not sever 'the comprehensive process involving [the objectivity of social existence and its relatedness to human subjectivity] in an inextricable interrelatedness', as Berger and Pullberg (1965: 197) describe the dialects of social life. Only in this way will we not forget that reification is the reversal of animation, that the reifact is a Fetischcharakter, and that reification is not an impediment to action but a condition for action.

To advocate, as I am doing here, a non-partisan and non-judgmental stance in the study of reification does not necessarily imply disengagement and apathy. Social scientists (particularly if they want change) should recognize that reification is a powerful means of intervention. Reifacts-fetishes most certainly enable the realization and extension of different forms of subjectivity and collective consciousness, forms that critical theorists may downplay as a distraction from the larger social issues that matter or straightforwardly condemn for facilitating the reproduction of the status quo and its acceptance as natural and inevitable. The solution to those reportedly distracting acts of fetishism, however, is not to eradicate fetishism from social life, for fetishism is part of who we are and the way we act.

Fetishism is also part of who scholars are and what they do, of course, as Berger, Luckmann and Pullberg readily acknowledged (Berger and Luckmann, 1966: 83-4; Berger and Pullberg, 1965: 205). Scholars are likely to reify their theoretical concepts, the tools of their trade, in addition to their other reifying peccadillos committed while they are not being scholars. 'Culture' leads to social violence, one scholar argues; 'the social environment x' produces excellence in sports, another scholar asserts; 'the super-ego' influences behavior, yet another scholar maintains. Marxian scholars reify the concept of reification as a magical force that turns people into objects but can, as well, in the hands of scholars, become a political tool that does things in the world, or could do things in the world if only the reified masses cared to listen the concept of reification is another reifact, another fetish. The concept of reification as a political weapon is per force reified. 
The problem, then, is not reification per se, which is colorblind, but what we do with it, for what reason, and to what purpose. Inspired by Gayatri Spivak's (1996 [1985]: 214) notion of 'strategic essentialism', I would therefore advocate not the eradication of reification once and for all, a doomed aspiration, but the responsible, critical and strategic deployment of reification as a tool for transformation.

\section{Acknowledgements}

I thank all those who attended the panel of the Society for the Anthropology of Religion 2011 biannual meeting in Santa Fe, New Mexico, where a preliminary version of this article was first presented and discussed. I am also deeply grateful to my anonymous reviewers for their intelligent and insightful comments and suggestions, to Eden Dotan and to Rik Scarce for their thorough reading of my final draft, and to the editorial team of Theory, Culture \& Society for their support, encouragement and professionalism.

\section{Notes}

1. For a genealogy of Marx's interest in fetishism (the analogy between economy and religion), see Pietz (1993).

2. According to political theorist Hanna Pitkin, Marx used the concept of reification in one casual passage in Capital, vol. III, chapter 48, 'where Marx calls the "reification [Verdinglichung] of social relationships" a "mystification" whereby the elements in the economist's "trinity formula" - capital, land, and labor - are "automized and ossified" in an "enchanted and inverted world"' (Pitkin, 1987: 264, quoting Marx).

3. In addition to Berger and Pullberg (1965), Berger and Luckmann (1966), Lukács (1971 [1923]) and Marx (1936 [1867]), see the following key references on reification: Adorno (1978, 2009 [1952]); Adorno and Horkheimer (2002 [1944]); Benjamin (1999); Bewes (2002); Gabel (1975); Honneth (2008); Jameson (1981); Pitkin (1987); Thomason (1982); and Woodard (1935).

4. On fetishism, see Blier (1995); Ellen (1988, 1990); Gell (1998); Godelier (1977); Goldman (2009); Graeber (2005); Hornborg (2006); Keane (1998, 2007); Latour (1993, 1999, 2010); Jackson (1998); MacGaffey (1990, 2000); Morgan (2010); Ochoa (2007, 2010); Pels (1998); Pietz (1985, 1987, 1988, 1993); Schiermer (2011); Silva (2011); and Taussig (1980).

5. For a similar attempt to bridge the insights of moderns and nonmoderns in the study of fetishism, see Bjørn Schiermer's (2011) thought-provoking essay 'Quasi-objects, cult-objects and fashion objects: on two kinds of fetishism on display in modern culture'.

6. The tendency to separate reification and animation as topics of study has given rise to two distinct and by and large mutually oblivious traditions of scholarship (see the references in notes 3 and 4, above). Noticeable exceptions to this general pattern are Brown $(2006)$, Ellen $(1988,1990)$ and Pels et al. (2002).

7. In addition to Berger, Luckmann and Pullberg, other authors who proclaim the universality and necessity of reification are Alfred Schutz (see Thomason, 1982: 88-138) and Joseph Gabel (1975: 155). More recently, writing at the center of the materialist turn in social and cultural theory, Bruno Latour 
$(1993,1999,2010)$ and Dick Pels (2002), to name only two, have argued that the answer to the old problem of what holds human societies together lies precisely in the fixity of material things.

8. For key references on ancestors and ancestral manifestations in northwest Zambia, see Silva (2011), Turner (1968), Wastiau (2000) and White (1948, 1949, 1961).

\section{References}

Adorno, T. (1978) Minima Moralia: Reflections from Damaged Life, trans. Jephcott E. London: Verso.

Adorno, T. (2009 [1952]) In Search of Wagner, trans. Livingstone R. London: Verso.

Adorno, T., with Horkheimer, M. (2002 [1944]) Dialectic of Enlightenment, trans. Jephcott E. Stanford, CA: Stanford University Press.

Benjamin, W. (1999) The Arcades Project, trans. Eiland H. and McLaughlin K. Cambridge, MA: Belknap Press of Harvard University Press.

Berger, P. and Pullberg, S. (1965) 'Reification and the sociological critique of consciousness', History and Theory 4(2): 196-211.

Berger, P.L. and Luckmann, T. (1966) The Social Construction of Reality: A Treatise in the Sociology of Knowledge. New York: Doubleday.

Bewes, T. (2002) Reification or the Anxiety of Late Capitalism. London: Verso.

Blier, S.P. (1995) African Vodun: Art, Psychology, and Power. Chicago: University of Chicago Press.

Brown, B. (2006) 'Reification, reanimation, and the American uncanny', Critical Inquiry 32(2): 175-207.

de Brosses, C. (1760) Du culte des dieux fétiches ou parallèle de l'ancienne religion de l'Egypte avec la religion actuelle de Nigritie. Paris: Fayard.

Ellen, R. (1988) 'Fetishism', Man 23(2): 213-235.

Ellen, R. (1990) 'Nuaulu sacred shields: the reproduction of things or the reproduction of images?', Etnofoor 3(1): 5-25.

Gabel, J. (1975) False Consciousness: An Essay on Reification, trans. Thompson M.A. Oxford: Basil Blackwell.

Gell, A. (1998) Art and Agency: An Anthropological Theory. Oxford: Clarendon Press.

Godelier, M. (1977) 'Fetishism, religion and Marx's general theories concerning ideology'. In: Perspectives in Marxist Anthropology, trans. Brain R. Cambridge: Cambridge University Press, 169-185.

Goldman, M. (2009) 'An Afro-Brazilian theory of the creative process: an essay in anthropological symmetrization', Social Analysis 53(2): 108-129.

Graeber, D. (2005) 'Fetishism as social creativity: or, fetishes are gods in the process of construction', Anthropological Theory 5(4): 407-438.

Honneth, A., with Butler, J., Geuss, R. and Lea, J. (2008) Reification: A New Look at an Old Idea, ed. Jay M. New York: Oxford University Press.

Hornborg, A. (2006) 'Animism, fetishism, and objectivism as strategies for knowing (or not knowing) the world', Ethnos 71(1): 21-32.

Jackson, M. (1998) Minima Ethnographica: Intersubjectivity and the Anthropological Project. Chicago: University of Chicago Press.

Jameson, F. (1981) The Political Unconscious. London: Methuen. 
Janzen, J.M. (1992) Ngoma: Discourses of Healing in Central and Southern Africa. Berkeley: University of California Press.

Keane, W. (1998) 'Calvin in the tropics: objects and subjects at the religious frontier'. In: Spyer, P. (ed.) Border Fetishisms: Material Objects in Unstable Spaces. New York: Routledge, 13-34.

Keane, W. (2007) Christian Moderns: Freedom and Fetish in the Mission Encounter. Berkeley: University of California Press.

Latour, B. (1993) We Have Never Been Modern. New York: Harvard University Press.

Latour, B. (1999) Pandora's Hope: Essays on the Reality of Science Studies. Cambridge, MA: Harvard University Press.

Latour, B. (2010) 'On the cult of the factish gods'. In: On the Modern Cult of the Factish Gods. Durham, NC: Duke University Press, 1-66.

Lukács, G. (1971 [1923]) History and Class Consciousness, trans. Livingstone R. London: Merlin Press.

MacGaffey, W. (1990) 'The personhood of ritual objects: Kongo Minkisi', Etnofoor 3(1): 45-61.

MacGaffey, W. (2000) Kongo Political Culture: The Conceptual Challenge of the Particular. Bloomington, IN: Indiana University Press.

Marx, K. (1936 [1867]) Capital: A Critique of Political Economy, vol. 1, trans. Moore S. and Aveling E., ed. Engels F. New York: Modern Library.

Morgan D. (ed.) (2010) Religion and Material Culture: The Matter of Belief. New York: Routledge.

Ochoa, T.R. (2007) 'Versions of the dead: Kalunga, Cuban-Kongo materiality, and ethnography', Cultural Anthropology 22(4): 473-500.

Ochoa, T.R. (2010) 'Prendas-Ngangas-Enquisos: turbulence and the influence of the dead in Cuban-Kongo material culture', Cultural Anthropology 25(3): $387-420$.

Pels, D. (2002) 'Everyday essentialism: social inertia and the "Münchhausen Effect", Theory, Culture \& Society 19(5/6): 69-89.

Pels, D., Hetherington, K. and Vandenberghe, F. (2002) 'The status of the object: performances, mediations, and techniques', Theory, Culture \& Society 19(5/6): 1-21.

Pels, P. (1998) 'The spirit of matter: on fetish, rarity, fact, and fancy'. In: Spyer, P. (ed.) Border Fetishisms: Material Objects in Unstable Spaces. New York: Routledge, 91-121.

Pietz, W. (1985) 'The problem of the fetish, I', Res 9: 5-17.

Pietz, W. (1987) 'The problem of the fetish, II: the origin of the fetish', Res 13: 23-47.

Pietz, W. (1988) 'The problem of the fetish, III: Bosman's Guinea and the Enlightenment theory of fetishism', Res 16: 103-123.

Pietz, W. (1993) 'Fetishism and materialism: the limits of theory in Marx'. In: Apter E. and Pietz W. (eds) Fetishism as Cultural Discourse. Ithaca, NY: Cornell University Press, 119-151.

Pitkin, H.F. (1987) 'Rethinking reification', Theory and Society 16: 263-293.

Schiermer, B. (2011) 'Quasi-objects, cult-objects and fashion objects: on two kinds of fetishism on display in modern culture', Theory, Culture \& Society 28(1): 81-102. 
Silva, S. (2011) Along an African Border: Angolan Refugees and Their Divination Baskets. Philadelphia, PA: University of Pennsylvania Press.

Spivak, G.C. (1996 [1985]) 'Subaltern studies: deconstructing historiography'. In: Landry D. and MacLean G. (eds) The Spivak Reader: Selected Works of Gayatri Chakravorty Spivak. London: Routledge, 203-236.

Taussig, M. (1980) The Devil and Commodity Fetishism in South America. Chapel Hill, NC: University of North Carolina Press.

Thomason, B.C. (1982) Making Sense of Reification: Alfred Schutz and Constructionist Theory. Atlantic Highlands, NJ: Humanities Press.

Turner, V. (1968) The Drums of Affliction. Ithaca, NY: Cornell University Press.

Wastiau, B. (2000) Mahamba: The Transforming Arts of Spirit Possession among the Luvale-Speaking People. Fribourg, Switzerland: Fribourg University Press.

White, C.M.N. (1948) 'Notes on some metaphysical concepts of the Balovale tribes', African Studies 7(4): 146-156.

White, C.M.N. (1949) 'Stratification and modern changes in an ancestral cult', Africa 19(4): 324-331.

White, C.M.N. (1961) Elements of Luvale Beliefs and Rituals. Manchester: Manchester University Press.

Whitehead, A. (1925) Science and the Modern World. New York: Macmillan.

Woodard, J.W. (1935) Intellectual Realism and Cultural Change: A Preliminary Study of Reification. Hanover, NH: Sociological Press.

Sónia Silva is Assistant Professor of Anthropology at Skidmore College. Her books include Along an African Border: Angolan Refugees and Their Divination Baskets (University of Pennsylvania Press, 2011). She is currently preparing a book-length manuscript that explores the transformative power of reification in ritual, art and politics. 